\title{
Insecticide Groups and Their Effects in Aquatic Environment
}

\author{
Figen Esin Kayhan ${ }^{1, *}$ Güllü Kaymak ${ }^{2}$, Nazan Deniz Yön ${ }^{2}$ \\ ${ }^{1}$ Marmara University, Faculty of Science and Arts, Department of Biology, Goztepe Campus, Goztepe, 34722, \\ Istanbul, Turkey. \\ ${ }^{2}$ Sakarya University, Faculty of Science and Arts, Department of Biology, Esentepe Campus, 54187, Sakarya, \\ Turkey.
}

\begin{abstract}
Over the past decade aquatic environments have become more contaminated by insecticides. Insecticides have a toxic effect on aquatic organisms and they become a part of the food chain by accumulation. Therefore it is very important to study the effects of subchronic exposure to environmental concentrations of insecticides on aquatic organisms. The aim of this review is to investigate different effects of insecticide groups on aquatic organisms in aquatic environment.
\end{abstract}

Keywords: Insecticides, Aquatic environment, Ecology

\section{İnsektisit Grupları ve Sucul Çevre Üzerine Etkileri}

\section{Özet}

Son y1llarda sucul çevredeki insektisitler oldukça önem kazanmıştır. Sucul çevrede insektisitlerin artışından beri insektisitlerin çevresel konsantrasyonlarına sürekli maruz kalan sucul organizmalardaki subkronik etkiler önemli çalışma konularıdır. $\mathrm{Bu}$ derleme çalışmasının amacı, farklı insektisit gruplarının sucul çevreye ve sucul organizmalar üzerine etkilerinin araştırılmasıdır.

Anahtar Kelimeler: İnsektisitler, Sucul çevre, Ekoloji 


\section{Introduction}

Pesticides are chemical substances that are used to reduce the destructive effects of living forms such as insects, rodents and herbs. Organisms that dwell in human and animal body and on or around the plants, reduce the nutritional value of the food sources or cause damage during production, storage and consumption [1,2,3]. Pesticides are named as insecticides, fungicides, herbicides, rodenticides, acaricides, nematocides according to the organism groups on which they have an effect. Nowadays, conscious nourishment trends, biological values of aquatic products and the fact that they have high protein qualities increase the significance of aquatic environments $[1,4,6]$. Economical utilization of natural water sources is as important as the utilization without contamination with respect to the potential of aquatic products. It is obvious that World's water sources are decreasing and becoming more contaminated every day. Domestic and industrial wastes can still be sent to the water sources despite all the measures taken. In the researches about water contamination, it has been declared that there are biochemical, histopathological, genotoxic and molecular changes in the tissue of the fish and these changes may be used as the indicators for determining the level of contamination. Using insecticides in huge amounts in agriculture leads to contamination not only when these insecticides accumulate in soil or water but also when they are poisonous to wild life, fish or other aquatic invertebrates. Like other pesticides, insecticides contaminate the seas, fresh waters, lakes and rivers in various ways. Thus, the fact that insecticides become a part of food chain and bioaccumulation of insecticides along these chains create serious problems in the ecosystem $[7,8,9]$. It has been found that such substances show an increase of about $10^{5}$. Bioaccumulation depends on the uptake, elimination ability of each organism and the physiochemical properties of the xenobiotic. The uptake from water or food depends on the water solubility of the xenobiotic and the trophic position of organism. While decreasing water solubility of toxicant and increasing trophic position, there is usually a greater accumulation from food. Insecticides bioaccumulation and biomagnification in fish and marine mammals were reported by several studies $[10,11,12]$. Toxicant biotransformation is usually related to metabolic rate, which increases from marine invertebrates to vertebrates and from fish to seabirds and mammals too. However, many seabirds show low ability in metabolizing pollutants and in increasing the bioaccumulation. Aquatic toxicology studies include the standardization of acute and chronic toxicity test methods, sediment toxicity and dietary assessments, and contaminant sensitivity studies of at risk species of concern including fish, amphibians and mollusks $[2,6,13,14]$. 


\section{Insecticide Groups: Organophosphates, Organochlorines, Pyrethroids and Carbamates:}

Insecticides are divided into four groups such as organophosphorus compounds, organochlorin compounds, carbamates and pyrethroids. Insecticide is a type of pesticide, which is generally used in areas such as agriculture, environmental health, human and animal health. While most of the pesticides contain different types of chemical substances that have various mechanisms of action, for the most part, they show their effects by disrupting the functions of the nerve system. In agricultural products, insecticides are commonly used worldwide for preventing degradation caused by the bugs. Insecticides have various chemical formulas depending on their intended use. Agrochemicals may be hazardous to the environment, because of their persistence, bioaccumulation and toxicity [15]. Until 1939, almost all agrochemicals consisted of inorganic and organic chemical substances and natural organic substances obtained from some plants. With the introduction of DDT (dichlorodiphenyltrichloroethane) as an agrochemical, synthetic organic insecticides found area of usage for the first time. As a result of the conducted studies, it has been reported that 50.000 tons of DDT have been used in whole biosphere since experts realized the pesticide aspect of DDT [16]. In organic and inorganic environments, amount of average DDT is respectively $10 \mathrm{ppm}$ in raptors feeding on fish and $2 \mathrm{ppm}$ in freshwater fish. In 1940's, many studies carried out by European scientists helped the development of organochlorine and organophosphate insecticides such as hexachloride (BHC), parathion, malathion, cypermethrin, deltamethrin and demeton-s methyl. According to the records of World Health Organization (WHO), today, there are more than 1500 chemical substances which are known as insecticide, fungicide, bactericide, herbicide, acaricide, aphicide, molluscicide, algaecide, avicide and rodenticide [17]. While most of the insecticides used can reach the target organisms, minority of them contaminate into non-target species, air, water, sediment and food $[18,19,20]$. As an ecotoxic example, in waterbirds that feed on the fish living in the waters contaminated by agricultural contaminants, the problem which emerges depending on the exposure period is that their egg shells become thinner. This case, which is observed in the birds, is a result of the existence of DDE (Diklorodifenildikloroetilen). Eggshells consist of calcium and calcium carbonate. As a result of repression of the enzymes, which is responsible for composition reaction due to DDE, egg shells are thinner than they are supposed to be. This causes the egg to break during incubation period. This situation is an example of how different organisms in the food chain are influenced by each other. In the areas with high agricultural potential, contamination reaches to levels that threaten the lives of not only the animals in nature but also humans [21,22]. In aquatic environment, insecticides are biological 
and chemical degradation resistant at different degrees; they bioaccumulate through the food chain causing human health and environmental damages. Insecticides may have a direct lethal effect depending on their chemical structure and the species of the affected fish. Moreover, they may also affect the habitat and therefore the food quality negatively [23]. Fish may get harmed by pesticides by absorbing them from aquatic environment via their branchia. Pesticides may affect the growth rates, breeding and behaviors of fish and damage their tissues. The damage it causes in the tissues may result in sensitivity in fish and lead them to be excessively affected by seasonal temperature changes and temporary hunger. Fingerlings, on the other hand, may be harmed by the pesticides more as they are more sensitive. Fish that are affected by the pesticides can be hunted by their enemies more easily. They also may be incapable of competing with other fish and may have low resistance on harsh conditions. Chemical contaminants, which get into aquatic environment from various other environments, may constitute saturation in terms of toxic and organic substance in harbors, bays and gulfs where circulation is weak [24]. As a result of this saturation, physiochemical balance of the environment is disrupted. Oxygen necessary for living and most of the phytoplankton species, which constitute the first level of the food chain, disappear. Apart from their toxic effects, chemical contaminants may also cause functional and histopathological defects in the digestion, circulation, excretion and nerve systems of the fish and other aquatic organisms. As a result of this, deterioration is observed in growth and proliferation standards. Agricultural chemicals' effect on the fish is different. While it may cause the fish to die directly, it may be effective on the fish population by preventing ovulation and proliferation. They also cause vulnerability (over sensitivity) in fish with their damages on tissues and organs. So, fish are affected by seasonal temperature changes and temporary starvation abundantly. Fingerlings are more harmed by this as they are more sensitive. It has been found out that there is an inverse relationship between insecticides' solubility in water and their accumulation in the fish's tissues and organs [25]. Aquatic organisms respond to contamination in two ways: acute and chronic. Acute effects may come up short after organism is exposed to high levels of contaminant. These effects may result in tissue and organ defects resulting in death of the organism. Chronic effects, on the other hand, are those which appear long after the organism is exposed to low concentrations of the contaminant. Insecticides, metabolization of which is difficult in the environment and the organisms and which tend to accumulate in the body, show chronic effects. Those with easy excretion easy cause acute poisoning [26]. Generally, average lifespan increases as the nourishment level gets higher and biomass (total weight of the organisms in a habitat) in the nourishment level decreases. In other words, pesticide 
concentration in the nourishment level increases. In any organism, pesticide concentration is directly proportional with the average lifespan of the group members and pesticides net presence in the organism. Also, it is inversely proportional with the total biomass [5]. Mobility of the agrochemicals in the water partly depends on solubility in the water, species of fish or the organism and formulation of the insecticide. Toxic effects of pesticides on aquatic organisms also depend on the $\mathrm{pH}$ and hardness of the water. For instance, it has been observed that toxic effect of Baylucide, which kills mollusks, is more active on the fish and snails in soft water than it is in hard water. It has been reported that Dipterex has a higher toxic effect in hard waters and $\mathrm{pH} 8.2$ and also its toxicity increase with higher temperature. It has been observed that toxic effect of Chlorpyrifos, Triflurarin and Dieldrin increase with the temperature in the water. Potential residue and time of insecticides also depend on the chemical structure of the medicine [14]. All insecticides cause serious negative effects on the ecosystem due to their toxic effects on nontarget organisms. Neurologic and behavioral activities of living organisms are very sensitive to environmental pollution. Effects of pesticides on the fish are observed in different ways. While it causes lethality in fish populations, it may also affect them by causing them to stop laying eggs and breeding. And again, they also cause the fish to be affected by seasonal temperature changes and temporary hunger excessively by causing sensitivity in the fish as a result of their damage on the tissues. Fish are particularly sensitive to water contamination, and pollutants may impair many physiological and biochemical processes when assimilated by fish tissue [27]. When abnormal xenobiotic-induced reactive oxygen species (ROS) production exceeds the endogenous protection, damage to cellular components can be often observed. This process is known as oxidative stress. The antioxidant defense system includes enzymes such as superoxide dismutase (SOD), glutathione peroxidase (GPx), catalase (CAT), glutathione Stransferase (GST), acetylcholinesterase (AChE) and other low molecular weight scavengers such as reduced glutathione (GSH). Fish are appropriate aquatic vertebrates to be used as environmental genotoxicity bioindicator organisms. This is due to both their role in the aquatic trophic chain and their sensitivity to low concentrations of genotoxic substances, which is characteristic of polluted aquatic environments $[13,28,29,30]$. In recent years, researches on genotoxicity in aquatic environments have used various tests, which were prepared for mammals to determine the clastogenic effects of contaminants. However, it was modified for many different aquatic organisms such as fish, mussels and crustaceans. Fish have an important place in such tests due to the fact that they can be preserved and grown more easily in laboratory environment. Micronucleus (MN) tests are significant for 
determining the genotoxic effects caused by contaminants. Genotoxic effects on fish can be evaluated by several techniques, especially by MN analysis in peripheral blood erythrocytes, a sensitive and reliable indicator of DNA damage. Micronuclei (MN) are structures, which are formed as a result of centromere or acentric - constituted as a result of diffractions in the chromosomes fragments' becoming chromatin as a result of disintegration. These structures are little structures which are separate from, but right next to the basic nucleus. Micronuclei can originate both from acentric fragments result in from chromosomal breaks which are not incorporated into the main nucleus and from whole chromosomes delayed during cellular division anaphase $[22,31]$. Due to the fact that fish generally have a large number of small chromosomes, there may be some difficulties in determining the clastogenic effects during metaphase studies. At this point, MN tests are frequently used as a practical, cheap and useful method. In a study, genotoxic effect of methyl parathion, which is an organophosphorus insecticide, on Capoeta trutta was researched by mean of micronucleus test. In the study, micronucleus erythrocyte frequency of the fish in the control group was $0.08 \%, 1.29 \%$ in the $125 \mathrm{ppm}$ low dose group and $2.56 \%$ in the $225 \mathrm{ppm}$ high dose group. It has also been observed that there is a direct proportion between dose increase and the number of micronucleus erythrocyte [32].

Organochlorines (OC): Organochlorine insecticides are adsorbed by planktons, algae, invertebrates, plants and fish in the food chain causing pesticide concentration in food chain to increase with time. Theoretically, if its concentration in water is established as 1 unit, it reaches 85.000 in a big fish and 80.000 in big sea birds as a result of the accumulation of organochlorine pesticide. Especially oysters and mussels serve well as bioindicators due to their capacity to pump water [8]. Pesticides carried into the atmosphere through the wind reach the sea via rain and atmospheric dust. The fact that pesticide remains are observed even in Antarctica is crucial in that it shows agricultural chemicals are carried to the nontarget areas. Methamidophos (MP) is a high activity, wide-spectrum, systemic/tactile and gastric effective insecticide. Its application is restricted. After the application, its minimum biological effect is 14 days and MP is average level toxic to the fish. After an application of 96 hours it is LC50 $25 \mathrm{mg} / \mathrm{L}$ in Oncorhynchus mykiss, $100 \mathrm{mg} / \mathrm{kg}$ in Carasius auratus and $100 \mathrm{mg} / \mathrm{kg}$ in Cyprinus carpio. This insecticide is also highly toxic to the bees [30]. In polluted areas, exposure of fish to insecticides leads to interactions between these chemicals and biological systems, which give rise to biochemical disturbances [33]. Organochlorine insecticides are capable of dwelling in the environment for a long time and accumulating in the body. Intake of organochlorine insecticide to the body and their accumulation property may increase 
incrementally by geometrical proportions depending on the organisms' position in the food chain. They may cause chronic poisoning even if they are in low doses. In addition, it is known that most of the insecticides accumulate in almost all of the tissues and they cause significant changes in hematological parameters. Especially organochlorine insecticides accumulate in the food chain widespread due to their lipophilic and hydrophobic natures and low chemical degradation velocity [15]. These substances, which tend to accumulate particularly in the adipose tissue, become free as the aquatic organisms burn their body fat when they cannot find food. Afterwards, they are incorporated into the circulation system and cause the death of the organism. Living and growth rates show decrease in the aquatic organisms, which are exposed to chemical substances for a long period of time. Fishes' response to the change in the natural living conditions in the aquatic environment results in different behavioral patterns, affect and balance disorders, changes in pathological period, beginning of critical state and threshold of death. Organochlorine insecticides cannot be excreted by natural ways as they disintegrate very slowly [2]. Most of them have a half-life of about 10-15 years. Pesticide residue that is incorporated into the body accumulates in the adipose parts of the body and cannot be filtered by blood easily. Thereby, rate of residue in the body of the organism increase slowly. Especially planktonic organisms accumulate adipose tissue in their bodies and eggs in order to be able to stay on the water surface. This causes the pesticides to accumulate more in zooplanktonic organisms. Organochlorines, which affect the endocrine glands, cause the number of eggs and spawning individuals to decrease in some bird and fish species due to their estrogenic effects. This can also lead to some fertilization problems and extinction of some species. For instance, it has been observed that the amount of Toxaphane, which is an insecticide used against cotton and soy bean pests, is $0.2 \mathrm{ppm}$ in the bodies of bugs which live in the muck and feed on herbaceous plants, 2-4 ppm in some zooplankton species, $8 \mathrm{ppm}$ in the muscles of the fish which feed on them, and $650 \mathrm{ppm}$ in the muscles of fish-eating birds. Methylparathion, which is an organophosphorus compound, was first used in 1922 in California Clear Lake for mosquito and sandfly contention. For this purpose, 3 ppb methylparathion was applied in the water for three times and three months [34]. Afterwards, it was observed that there was a sudden decrease in Copepod (Cyclops spp., and Diaptomus spp.,) and Cladocera (Daphnia spp.) species, but then their numbers started to increase. Mussels are also one of the aquatic organisms that are affected negatively by the pesticides since they filter water 20.000 times as much as their own weight. Therefore, pesticides and heavy metal residues have more effect on these organisms [25]. According to a research in which effects of various doses of malathion $(0.5,1.0$ and 1.5 
$\mathrm{ppm}$ ) on the egg growth of zebrafish (Danio rerio) was surveyed, the time for the zebrafish to leave the chorion and their height and exit pupil diameter decrease. It is known that biological transformation of chemical contaminants is more efficient in crustacean and benthic zone organisms than in fish. Due to the fact that mussels feed by filtering the water in the ambience and they lead a sessile life, they are significant organisms for determining water contamination. In a research conducted on $\mathrm{OC}$, it was found that the highest $\mathrm{OC}$ concentration (507 ng/g fat tissue) was in Sardina pilchardus (European pilchard) and the lowest OC concentration was in cephalopods [11].

Organophosphates (OP): Organophosphates are complex structured organic substances, which contain phosphor. In 1950's they were synthesized as insecticides. The most common pesticide group is organophosphate. These compounds, which are esters of phosphoric acid, are classified according to the radicals bound to phosphor particles. Toxicity may vary according to the molecule, pharmaceutical form and the affected animal species. Cats, waterfowls, bees and fish are relatively the most sensitive species. Organic phosphoric compounds are cholinesterase inhibitors. Organophosphates have same toxicity levels on vertebrate and invertebrate organisms even in low concentrations $(\mathrm{ng}-\mu \mathrm{g} / \mathrm{mL})$; they cause toxicity especially in the fish [4]. Organophosphates show their main effects by inhibiting some enzymes' effect in aquatic vertebrate and invertebrate organisms. For instance, they cause a toxic effect by inhibiting acetylcholinesterase enzyme (AChE), which is responsible for terminating transmission in nerve impulses in fish. Acetylcholyn is one of the most common neurotransmitters in the body. Organophosphates cause excessive accumulation of $\mathrm{ACh}$ and activation of $\mathrm{ACh}$ receptors by blocking the hydrolysis of the acetylcholine (ACh) in central, peripheral, neuronal synapses [15]. For instance, malathion is an organophosphoric insecticide which has a high toxicity for fish. As its half-life is very short, excessive accumulation is not observed in aquatic organisms. Organophophorus (OP) compounds are widely used for agriculture and domestic purposes when controlling insect pests. Due to their rapid breakdown in water and their low environmental persistence, OP's have largely replaced the use of OC's in recent years. Responses of OP insecticides by aquatic organisms are broad ranged depending on the compound, exposure time, water quality and the species. In this regard, fish are particularly sensitive to OP's. Organophosphates may enhance lipid peroxidation by direct interaction with the cell membrane. AChE enzyme is widely used for rapid detection to predict early warning of pesticide toxicity [16]. The most common action mechanism of organophosphate insecticides is the inhibiton of acetylcholinesterase (AChE) enzyme. While insecticide residues in natural waters cause $\mathrm{AChE}$ inhibition in fish, it also 
affects the resynthesis and hormonal regulation of the enzyme. Brain AChE inhibition will certainly decrease the survival skills of a fish, which is very important in the early phases of growth. Moreover, it causes physiological and behavioral modifications. The inhibitory effects of OP insecticides are dependent on their binding capacity to the enzyme active site and by their rate of phosphorylation in relation to the behavior and age. For example, Trichlorfon (dimethyl, (2,2,2-trichloro-1-hydroxyethyl) phosphonate) is a selective organophosphate insecticide used to control a variety of arthropod pests. Araki et al. (2003) found a trichlorfon half-life in the water lesser than 17 days. The trichlorfon half-life in the fish was 12 days and the dissipation time of 95\%-trichlorfon in the fish was 50 days. Experiments of some researchers, using the trichlorfon in blue common mussel (Mytilus edulis) and native oyster (Ostrea edulis) allowed to estimate the trichlorfon half-life in blue mussel hepatopancreas (17 days) and adductor muscle (4 days) and in native oyster hepatopacreas (13 days) and adductor muscle (8 days) [35]. Although the low bioconcentration potential and the short half-life found for trichlorfon in the water, Chandrasekara and Pathiratne (2005) observed hematological alterations in common carp (Cyprinus carpio) exposed to 0.25 and $0.50 \mathrm{mgl}^{-1}$ of trichlorfon during $24 \mathrm{~h}$. Researchers observed histopathological alterations in kidney tissues of Prochilodus lineatus induced after a $24 \mathrm{~h}$ exposition to sublethal trichlorfon concentrations $\left(0.2 \mu 1 \mathrm{l}^{-1}\right)$ and in shrimps (Macrobrachium rosenbergii) trichlorfon is immunosuppressor, reducing shrimp resistance to virus and bacteria diseases [7,10,14,23].

Carbamates: Carbamates are the newest and miscellaneous insecticides. They are prevalently used against fungus and herbs. Carbamate ester derivatives used as insecticides are decisive. Hydrolyzation of carbamate group insecticides is very slow in acidic and alkali waters. Halflife of carbamates in aquatic environment is about 1-32 days. They have low solubility in low vapor pressure and aquatic environments. Although carbamate group insecticides cannot remain in environment for a long time and are not very resolved, they may accumulate in the fish since fish have a slow metabolism. Their toxic effects to aquatic organisms vary depending on the compound types and species. The basic catabolite is 1-naphtol. While it is generally an average toxic effect for the fish, it has a high level of toxicity for some of invertebrate species [23]. Carbamates may also accumulate in fish in small amounts due to the fact that they have slow metabolisms. For example, among the carbamate pesticides, Pirimicarb is a selective insecticide used mostly for aphid control. Available information indicates that 23 formulated products containing pirimicarb as an active ingredient have been registered worldwide. Some of these pirimicarb-containing formulations have been reported 
to induce toxic effects in the crustaceans Ceriodaphnia quadrangula and Daphnia magna, in fish such as Poecilia reticulata and Cyprinus carpio. Genotoxic studies of pirimicarb are scarce. In a study, acute toxicity of carbaryl, which is a potential contaminant in aquatic ecosystems and a carbamate derivative, was analyzed. According to the study, for European chub (Leuciscus cephalus), LC50 value for 96 hours was observed to be $8.66 \mathrm{mg} \mathrm{1-1.} \mathrm{This}$ value is $0.25 \mathrm{mg} \mathrm{1-1}$ for Atlantic salmon (Salmo salar), $20 \mathrm{mg} \mathrm{1-1} \mathrm{for} \mathrm{Black} \mathrm{bullhead}$ (Ameiurus melas); it is more toxic to the invertebrates [36].

Pyrethroids: Pyrethroid insecticides are used preferably over organochlorine and organophosphates due to their potent insecticidal properties and are practically nontoxic to most nontarget animals, especially mammals [24]. Pyrethroids also have synthetic analogs. These are bioresmethrin, permethrin, cypermethrine and deltamethrin. Pyrethroids have a short life in most animals as they are readily metabolized. Fish are an exception, since they seem to be deficient in the enzyme system that hydrolyzes pyrethroid. Due to their lipophilicity, pyrethroids easily permeate through the gills, which is contributing factor in the sensitivity of the fish to aqueous pyrethroid exposures [12]. Pyrethroids extracted from Chrysanthemum cinerariaefolium plant are widely used against cotton and other plant mites and for human consumption, against external parasites. Since they can disintegrate rapidly, their toxicity levels are low in winged animals and mammals. However, they are toxic molecules for the fish. High concentrations of pyrethroids cease the growth of the egg in fish before the blastopore closes. During these stages, if high rates of death are observed in the unfertilized embryo, it indicates that embryonic stage is more sensitive to pyrethroids. In the struggle against fungus in the fish and their eggs, while it is used for protozoa infections, it is a toxic chemical for the fish. Insecticides dissolved in the water are generally absorbed by the fish via their branchia, skin and food. Therefore, histological studies are carried out as the complementary to the toxicological test results. Even if aquatic organisms are subjected to very low quantities of insecticide, this causes many biochemical, physiological and histological changes in their bodies $[1,6,30]$. In aquatic organisms, branchia is a vital limb, in that it has a significant role in the transmittance of respiratory gases and provision of osmotic and ionic equilibrium. Since toxic substances cause damages in the branchia tissue of aquatic organisms, such disruptions cause the decrease in oxygen consumption and failures in osmoregulation system. It has been observed that swelling, epithelial histolysis, hyperplasia and purulent changes occur in the branchia of various fish, which are subjected to insecticides. In a study, when rainbow trout, which were subjected to carbaryl, were analyzed histologically, it was observed that there were oedemas in the branchia lamella, epitheliums 
disintegrate from the lamella, lamellas integrate and distensions occurred in epithelium cells. In general, it has been determined that carbaryl metabolites don't accumulate in animal tissues, and quickly transform into substances which don't have any toxic effects and which are destructible in urine and excretion. In similar studies that were carried out by using carbamate group pesticides, it has been reported that oedema and necrosis develops in the branchia lamella of trout. In these studies, it has also been determined that carbaryl causes corrosion in the branchia membranes of the fish, degeneration in the branchia lamella and that such defects cause deaths by affecting the respiratory systems of the fish [24]. For instance, deltamethrin is a widely used synthetic pyrethroid. High concentrations of pyrethroid hinder the growth of the eggs before blastopore closes. The fact that mortality rate in zygote is high during these phases shows that earlier embryonic phases are more vulnerable to the pyrethroids. In a recent study, zebrafish (Danio rerio) embryos were exposed to paraoxonethyl insecticide for specific periods of time and colin and carboxylesterase activities were observed. It has been observed that this enzyme increased in parallel with this development while a significant decrease was observed in the groups to which insecticide was applied. In another research, it has been reported that there were deformations in the configuration of the tail on the vitellus caecum and somite configuration. It has also been reported that in zebrafish which are exposed to various doses deltamethrin, primordial germ movement slows down $(0.4 \mu \mathrm{g} / \mathrm{l})$ high doses $(1 \mu \mathrm{g} / \mathrm{l})$ stops the cell migration and lead to changes in the cell morphology. Synthetic pyrethroids neither become fully metabolized nor can they lose their toxicity in a short period of time [9,34]. Therefore, their residues and accumulations cause serious problems. Heavy contamination of pesticides in the aquatic environment lead to oxygen scarcity and thereby lead to poisoning cases and aggregate death of the fish. Synthetic pyrethroids are more toxic other aquatic organisms than they are for fish. Accumulation of pyrethroids in adipose tissue, shows that these chemicals are observed by the fish even when they are present in the water in low concentrations. For instance, cypermethrine is highly toxic to the fish and aquatic invertebrates. LC50 (95 hours) value is $0,0082 \mathrm{mg} / 1$ for rainbow trout. Metabolism and excretion of cypermethrin is quite slow in the fish compared to mammals and birds. This indicates that this compound is more toxic for the fish compared to other organisms [24]. While excretion of various pyrethroids in the birds and mammals is about 6-12 hours, it is 48 hours in the trout. Like all pyrethroids "Bifenthrin" is highly toxic to fish, interfering with $\mathrm{Na}^{+}$channel gating in the nerve cell endings, but other ion channels such as $\mathrm{Cl}^{-}$and $\mathrm{Ca}^{+}$channels can be targeted as well [37]. This leads to continuous neurotransmission causing hyperexcitability, tremors, convulsions and finally 
death. The fact that physical and chemical characteristics of the water (dissolved oxygen, ammoniac, hardness, $\mathrm{pH}$, gas content, partial pressure, temperature etc.), heavy metals $(\mathrm{Cd}$, $\mathrm{Pb}, \mathrm{Hg}, \mathrm{As}, \mathrm{Fe}$ etc.), agricultural chemicals (insecticide, herbicide, fungicide etc.) and such contaminants as chlorine, cyanide, phenol and polychlorobiphenyl lead to stress in aquatic organisms. Stress proteins produced by the aquatic organisms as a response to these factors are appropriate biomarkers for determining the effects of contaminants on a cellular level. In recent years, stress proteins have been used as indicators of environmental pollution. These proteins were first reported in the salivary gland of fruit fly (Drosophila busckii) that was exposed to high temperature and were defined as heat shock proteins (Hsp). When it was found out that these proteins are synthesized by other factors as well, they were named "stress proteins". Although this definition includes such protein groups, which are induced by stress as metallothionine, cyttochrome P450 and Hsp's, it is generally called Hsp in terminology. Hsp is a cellular protein group, which shows high degrees of similarity on the amino-acid level among various organisms. It has been suggested that stress proteins are significant biomarkers of toxicity for aquatic organisms (algae, protozoa, rotifera, mollusca, arthropoda, crustaceans, fish etc.). In recent years, an increasing number of researchers have focused on this subject. There have been several efforts to validate the use of the Hsp response as an indicator of stressed states in fish. It has been shown that several forms of environmental stressors may induce the Hsp response in fish. For example, increased levels of various Hsp's have been measured in tissues of fish exposed to industrial effluents, polycyclic aromatic hydrocarbons, several metals such as copper, zinc and mercury and pesticides [1, 29, 38].

Conclusion: All aquatic organisms are capable of rapidly and actively adapting themselves to the stress caused by sudden environmental changes due to the fact that they live in a dynamic environment. However, it is obvious that this adaptation leads to a loss of energy in terms of growth and proliferation. Adaptation is an effective process over a short term and it increases the survival chances of the animal. If the stress values continue chronically, physiological adaptation will stop functioning after a while, and the organism will be in the tolerance status and become insensitive to other stress factors. This process results in the death of the organism in the long term. Compositions and structures of the species living in the aquatic ecosystem may develop as a result of their high sensitivity to industrial and domestic wastes. Therefore, diversity of organisms may be harmed. Each research conducted on aquatic organisms will play a significant role for determining the effect of increasing chemical substance diversity on aquatic ecosystems. 


\section{References}

[1] Valavanidis, A., Vlahogianni, T., Dassenakis, M. and Scoullos, M. (2006). Molecular biomarkers of oxidative stress in aquatic organisms in relation to toxic environmental pollutants. Ecotoxicology and Environmental Safety, 64: 178-189. doi.org/10.1016/j.ecoenv.2005.03.013.

[2] Candioti, JV., Soloneski, S., Larramendy, ML. (2010). Genotoxic and cytotic effects of the formulated insecticide Aficida on Cnesterodon decemmaculatus (Jenyns, 1842) (Pisces: Poeciliidae). Mutation Research/Genetic Toxicology and Environmental Mutagenesis, 703: 180-186. doi: 10.1016/j.mrgentox.2010.08.018.

[3] Choung, C.B., Hyne, R.V., Stevens, M.M., and Hose, G.C. (2013). The ecological effects of a herbicide insecticide mixture on an experimental freshwater ecosystem. Environmental Pollution, 172: 264-274. doi: 10.1016/j.envpol.2012.09.002.

[4] Cox, C. and Surgan, M. (2006). Unidentified inert ingredients in pesticides: implications for human and environmental health. Environmental Health Perspectives, 114: 1803-1806. doi: 10.1289/ehp.9374.

[5] Hayasaka, D., Korenaga, T., Suzuki, K., Saito, F., Sánchez-Bayo, F., Goka. K. (2012). Cumulative ecological impacts of two successive annual treatments of imidacloprid and fipronil on aquatic communities of paddy mesocosms. Ecotoxicology and Environmental Safety, 80, 355-362. doi.org/10.1016/j.ecoenv.2012.04.004.

[6] Boone M.D., Hammond S.A., Veldhoen N., Youngquist M., Helbing C.C. (2013). Specific time of exposure during tadpole development influences biological effects of the insecticide carbaryl in green frogs (Lithobates clamitans). Aquatic Toxicology, 130-131,139148. doi: 10.1016/j.aquatox.2012.12.022.

[7] Yeh, S.P., Sung, T.G., Chang, C.C., Cheng, W. and Kuo, C.M. (2005). Effects of an organophosphorus insecticide, trichlorfon, on hematological parameters of the giant freshwater prawn, Macrobrachium rosenbergii. Aquaculture, 243: 383-392. doi:10.1016/j.aquaculture.2004.10.017. 
[8] Li, H., Mehler, W.T., Lydy, M.J., You, J. (2011). Occurrence and distribution of sediment associated insecticides in urban waterways in the Pearl River Delta, China. Chemosphere, 82: 10, 1373-1379. doi: 10.1016/j.

[9] Güneş, E. and Yerli, S.V. (2011). Effects of deltamethrin on lipase activity in Guppies (Poecilia reticulata). Turkish Journal of Fisheries and Aquatic Sciences, 11: 473-476. DOI: 1010.4194/1303-2712-v11_3_19

[10] Chandrasekara, H.U. and Pathiratne, A. (2005). Influence of low concentrations of trichlorfon on haematological parameters and brain acetylcholinesterase activity in common carp, Cyprinus carpio. Aquaculture Research, 36: 144-149. DOI: 10.1111/j.13652109.2004.01197.x.

[11] Deng, J., Yu, L., Liu, C., Yu, K., Shi, X., Yeung, L.W., Lam P.K., Wu R.S. and Zhou B. (2009). Hexabromocyclododecane-induced developmental toxicity and apoptosis in zebrafish embryos. Aquatic Toxicology, 93: 29-36. doi: 10.1016/j.aquatox.2009.03.001.

[12] Forsgren, K.L., Riar, N., Schlenk, D. (2013). The effects of the pyrethroid insecticide, bifenthrin, on steroid hormone levels and gonadal development of steelhead (Oncorhynchus mykiss) under hypersaline conditions. General and Comparative Endocrinology, 186, 101107. doi.org/10.1016/j.ygcen.2013.02.047.

[13] Livingstone, D.R. (2001). Contaminant-stimulated reactive oxygen species production and oxidative damage in aquatic organisms. Marine Pollution Bulletin, 42: 656-666. PMID:11525283.

[14] Rivadeneira, P.R., Agrelo, M., Otero, S., Kristoff, G. (2013). Different effects of subchronic exposure to low concentrations of the organophosphate insecticide chlorpyrifos in a freshwater gastropod. Ecotoxicology and Environmental Safety, 90:82-88. doi.org/10.1016/j.ecoenv.2012.12.013.

[15] Kristoff, G., Cacciatore, L.C., Verrengia Guerrero, N.R., Cochón, A.C. (2011). Effects of the organophosphate insecticide azinphos-methyl on the reproduction and cholinesterase activity of Biomphalaria glabrata. Chemosphere, 84: 585-591. doi: 10.1016/j. 
[16] Rao JV. (2006). Toxic effects of novel organophosphorus insecticide (RPR-V) on certain biochemical parameters of euryhaline fish, Oreochromis mossambicus. Pesticide Biochemistry and Physiology, 86:(2), 78-84. doi.org/10.1016/j.pestbp.2006.01.008.

[17] WHO (2003). Food based dietary guidelines in the World Health Organization European Region. Report EUR/03/5045414athttp://who.org>2003. Cenevre, İsviçre.

[18] Patil, V.K. and David, M. (2008). Behavior and respiratory dysfunction as an index of malathion toxicity in the freshwater fish, Labeo rohita (Hamilton). Turkish Journal of Fisheries and Aquatic Sciences, 8: 233-237.

[19] Stalin, S.I., Kiruba, S., and Monohar Das, S.M. (2008). A comparative study on the toxicity of a synthetic pyrethroid, deltamethrin and a neem based pesticide, Azadirachtin to Poecilia reticulata Peters 1859 (Cyprinodontiformes: Poeciliidae). Turkish Journal of Fisheries and Aquatic Sciences, 8:01-05.

[20] Salaberria, I., Hansen, B.H., Asensio, V., Olsvik, P., A Rolf., Andersen, P.R. and Jenssen, B.M. (2009). Effects of atrazine on hepatic metabolism and endocrine homeostasis in rainbow trout (Oncorhynchus mykiss). Toxicology and Applied Pharmacology, 234: 98-106. doi.org/10.1016/j.taap.2008.09.023.

[21] EPA (1999). Environmental Protection Agency, Office of Pesticide Programs Health Effects Division (7509C) Washington, USA.

[22] Könen, S. and Cavaş, T. (2008). Genotoxicity testing of the herbicide trifluralin and its commercial formulation Treflan using the piscine micronucleus test. Environmental and Molecular Mutagenesis, 49: 434-438. DOI: 10.1002/em.20401.

[23] Sultatos, L.G. (2008). Interactions of organophosphorous and carbamate compounds with cholinesterases. In: R.C. Gupta, Editor, Toxicology of Organophosphorus and Carbamate Compounds, Elsevier Academic Press, Burlington. 209-218. 
[24] Mishra, D., Tripathi, S., Srivastav, S., Suzuki, N., Srivastav, A.K. (2010). Corpuscles of stannius of a teleost Heteropneustes fossilis following intoxication with a pyretroid (cypermethrin). North-Western Journal of Zoology, 6:2, 203-208. P-ISSN: 1584-9074, EISSN:1843-5629.

[25] Stark, J.D. and Walthall, W.K. (2003). Agricultural adjuvants: acute mortality and effects on population growth rate of Daphnia pulex after chronic exposure. Environmental Toxicology and Chemistry, 22: 3056-3061. DOI: 10.1897/02-504.

[26] Dutta, H.M. and Arends, D.A. (2003). Effects of endosulfan on brain acetylcholinesterase activity in juvenile bluegill sunfish. Environmental Research. 91: 157162. PMID:12648478.

[27] Oakes, K.D. and Van Der Kraak, G.J. (2003). Utility of the TBARS assay in detecting oxidative stress in white sucker (Catostomus commersoni) populations exposed to pulp mill effluent. Aquatic Toxicology, 63: 447-463. PMID:12758008.

[28] Alvarez, R.M., Morales, A.E. and Sanz, A. (2005). Antioxidant Defences in Fish: Biotic and Abiotic Factors. Reviews in Fish Biology and Fisheries, 15: 75-88. doi.org/10.1016/j.aquaculture.2005.11.020.

[29] Scandalios, J.G. (2005). Oxidative stress: Molecular perception and transduction of signals triggering antioxidant gene defenses. Brazilian Journal of Medical and Biological Research, 38: 995-1014.ISSN-0100-879X.

[30] Zhang, X., Xie, P., Li, D., Tang, R., Lei, H. and Zhao, Y. 2009. Time-Dependent Oxidative Stress Responses of Carassius auratus to Intraperitoneal Injection of Extracted Microcystins. Bulletin Of Environmental Contamination and Toxicology, 82: 574-578.DOI. $10.1007 / \mathrm{s} 00128-009-9671-2$.

[31] Cavaş T. and Könen S. (2007). Detection of cytogenetic and DNA damage in peripheral erythrocytes of goldfish (Carassius auratus) exposed to a glyphosate formulation using the micronucleus test and the comet assay. Mutagenesis, 22: 263-268. doi:10.1093/mutage/gem012. 
[32] Cavaş, T. and Ergene-Gözükara, S. (2005). Micronucleus test in fish cells: a bioassay for in situ monitoring of genotoxic pollution in the marine environment. Environmental and Molecular Mutagenesis, 46: 64-70. PMID:15880416.

[33] Joy, V.C., Pramanik, R. and Sarkar, K. (2005). Biomonitoring insecticide pollution using non-target soil microarthropods. Journal of Environmental Biology, 26: 571-577. PMID: 16334299.

[34] Nkya, T.E., Akhouayri, I., Kisinza, W., David, J.P. (2013). Impact of environment on mosquito response to pyrethroid insecticides: Facts, evidences and prospects. Insect Biochemistry and Molecular Biology, 43:4,407-416. DOI:10.1016/j.ibmb.2012.10.006

[35] Araki D., Takase I. and Motoyama N. (2003). Leaching of pesticides applied to an experimental putting green and their fate in a reservoir, Journal of Pesticides Sciences, 28: 76-82.ISSN:0385-1559.

[36] Ferreira, M., Moradas-Ferreira, P. and Reis-Henriques, M.A. (2005). Oxidative stress biomarkers in two resident species, mullet (Mugil cephalus) and flounder (Platichtkys flesus), from a polluted site in River Douro Estuary, Portugal. Aquatic Toxicology, 71: 39-48. PMID:15642630.

[37] Burr S.A. and Ray D.E. (2004). Structure-activity and interaction effects of 14 different pyrethroids on voltage-gated chloride ion channels, Toxicological Sciences, 77: 341-346. PMID:14657519.

[38] Kayhan, F.E. and Süsleyici Duman, B. (2010). Heat shock protein genes in fish. Turkish Journal of Fisheries and Aquatic Sciences, 10:287-293. DOI: 10.4194/trjfas.2010.0218. 